\title{
Resource use, dependence and vulnerability: community-resource linkages on Alaska's Tongass National Forest
}

\author{
E. T. Mekbeb ${ }^{1}$, R. J. Lilieholm ${ }^{2}$, D. J. Blahna ${ }^{3}$ \& L. E. Kruger ${ }^{3}$ \\ ${ }^{I}$ Department of Environment \& Society, Utah State University, USA \\ ${ }^{2}$ School of Forest Resources, University of Maine, USA \\ ${ }^{3}$ US Forest Service, Pacific Northwest Research Station, USA
}

\begin{abstract}
Understanding how rural communities use and depend upon local natural resources is a critical factor in developing policies to sustain the long-term viability of human and natural systems. Such "community-resource" linkages are particularly important in Alaska, where rural communities - many of them comprised of indigenous Alaskan Natives - are highly dependent upon local resources found on public lands. Alaskan communities utilize forests in many ways. To better understand these coupled "social-ecological" systems, we combined socio-economic data from the 2000 U.S. Census with timber permit data from the USDA Forest Service to describe communities and their use of forest resources. Our results suggest that private access to public resources is an important feature of Alaskan communities, and that continued access is likely to be a key factor in sustaining human systems on the landscape. As a result, public land managers should give special consideration to local resource use when making policy decisions.
\end{abstract}

Keywords: economics, ecosystem management, environmental services, timberdependent communities, resilience, social capital, sustainable development.

\section{Introduction}

Social views over the appropriate management and use of public forest lands in the U.S. have undergone tremendous change over the last 40 years [1]. During this transition, public land management has evolved from providing marketed commodities like timber, to the protection and maintenance of ecosystem 
services under the paradigm of ecosystem management [2]. The change is manifest through a host of laws, including the National Environmental Policy Act (1969), the Endangered Species Act (1973), the Resources Planning Act (1974), the National Forest Management Act (1976), and others. These laws have profoundly altered the management of hundreds of millions of acres of public forests, perhaps none more so than the 191 million acres managed by the USDA Forest Service (USFS).

Amid changing public views over resource management, the State of Alaska presents an interesting paradox. There, growing demands for recreational uses and environmental protection increasingly conflict with long-standing demands for extractive uses. These traditional uses - including mining, logging, firewood cutting, and hunting - support many rural Alaskan communities, especially Native communities. The potential for conflict is particularly high in Alaska, where nearly $89 \%$ of the land base is publicly owned, $10 \%$ is under Native corporate control, and just $1 \%$ is privately held. For public lands, $27 \%$ are managed by the State, with the balance under federal control, including $6 \%$ managed by the USFS.

Nearly $40 \%$ of Alaskans live in rural communities with fewer than 10,000 residents. Moreover, nearly $17 \%$ of Alaskans are Alaska Natives with $69 \%$ living in rural communities. Alaska's many rural communities, combined with the State's dominance of public lands, makes local access to public resources a critical issue. Yet this historic connection between communities and land management agencies like the USFS is challenged by national trends that shift management away from commodity production (i.e., timber), to greater emphasis on cultural values (e.g., spiritual, recreational and aesthetic) and ecological services (e.g., regulating and supporting services like wildlife habitat and water quality).

The purpose of this paper is to provide a conceptual review of key concepts needed to better understand and measure how rural communities access and use nearby public land resources - what we call "community-resource linkages." We first review the literature on the nature of community, resource dependence, and vulnerability, and then describe how the USFS manages private use of public lands. Finally, we present a methodology that uses USFS permit data in Southeast Alaska to describe resource use at the community level in order to foster an improved understanding of community-resource linkages as a way to ensure the sustainability of human and natural systems.

\subsection{The concept of community}

Communities can be defined in many ways. Wilkinson [3] described the concept of community as having three components: (1) a "locality" where people live and meet their daily needs; (2) a "local society" embodying a network of associations for meeting common needs and expressing common interests; and (3) a "community field" where residents meet and express issues of shared concern related to the locality. These attributes of geography, networks, and interests are widely noted in the literature [4]. 
For many, "community" is often based on a shared "sense of place" which involves relationships between people, cultures, and environments - both natural and built - associated with a particular area [5]. Such notions of "place dependence" convey the view that a location is unique in its ability to satisfy economic and non-economic needs of individuals or communities. Community can also be defined as a "community of interest," where people are linked by a common interest, activity, or value [6]. For Alaskan communities, place dependence and local use of nearby resources are powerful forces that shape the notion of community. Whether based on tribal custom or economic necessity, local use of public lands is central to everyday life for many Alaskans.

\subsection{Resource dependence and rural communities}

The welfare and sustainability of rural resource-based communities is an important social goal for land management agencies. Indeed, Berck et al. [7] suggest that a primary motive in defining forest dependency is its relevance for policy. Resource dependence can be defined using economic, technological, and socio-cultural metrics. Kaufman and Kaufman [8] studied forest dependence more than a half-century ago, focusing on sustained yield's role in supporting forest sector employment and local economic development. Most efforts to describe resource dependence have utilized economic approaches based on employment and income statistics to measure the proportion of economic activity linked to specific industries. For decades, the conventional wisdom was that forest-based employment was linked to higher incomes and benefits [9].

More recently, however, the relationship between sustained timber yield and community stability has been questioned, with studies finding that dependence on logging may expose communities to high unemployment and related social ills [10]. Indeed, most social scientists today view the concept of "community stability" as overly simplistic, noting that social communities - like their ecological counterparts - experience constant change. As a result, community research increasingly seeks to understand the factors that underlie community resilience and adaptation to change $[11,12]$.

Today, many researchers agree that understanding and measuring forest dependence requires multiple approaches. Common to these approaches is the search for indicators that, once identified, are easy to measure, compare, and monitor. Examples include indices based on socio-economic variables, researcher-identified and process variables, and subjective self-reports [13]. Others have developed indicators that include community resilience, social capital, and sense-of-place concepts $[14,15]$.

\subsection{Resource access and community vulnerability}

Patterns of resource dependence emerge in a variety of settings, but primarily involve communities in which economic activity revolves around capitalizing on key features of the local natural environment - typically agriculture, forestry, fisheries, mining, oil and gas extraction, or recreation and tourism. Such communities often have a history of economic insecurity due to industry 
fluctuations, technological change, globalization, and shifting state and federal resource policies [16]. Factors that may exacerbate vulnerability include reliance on a single industry, isolation from population centers, small and/or aging populations, and low levels of income and education. In combination, these factors expose communities to external stresses.

Blaikie et al [17] defined community vulnerability as "the lack of capacity to anticipate, cope with, resist, and recover" from some impact. The concept has been examined within many contexts, including susceptibility to climate change and adaptive responses, food insecurity, and natural hazards. The concept has particular relevance for Alaska, where resource linkages are central to rural identity, yet subject to changing state and federal natural resource policies.

\subsection{The importance of scale in describing resource linkages}

Regardless of how community-resource linkages are defined, the concept of scale - a topic that has received limited attention in the literature - is critical. Cash et al [18] define scale as "the spatial, temporal, quantitative, or analytical dimensions used to measure and study any phenomenon." The issue of scale is important in understanding what forests mean to people, and is critical in understanding community impacts and the institutional linkages between government agencies and other entities [19].

As noted earlier, resource dependence is typically considered in relation to commodity production and associated impacts on employment and income. Moreover, due to data or reporting limitations, such considerations are typically focused at the county or state level - a level of aggregation that may obscure important community-level relationships between people and landscapes. For example, many Alaskans have engaged in subsistence practices for generations, and regard the forest as a source of goods and services available to satisfy a host of material and spiritual needs. In contrast, the USFS has a national mandate to manage Alaska's National Forests at a broader scale where the resource is defined and valued by non-local or "outside" interests. Hence, the USFS must juggle the mixed mission of satisfying State and national interests while fostering the sustainability of Alaska's rural communities and local ecosystems.

\subsection{Describing community-resource linkages at the community level}

Understanding the nature of community-resource linkages in the context of private use of public lands is critical to sustaining human and natural systems. These linkages can vary considerably, depending on the resources available, land management policies, and the community's cultural, demographic, and economic characteristics. Endter-Wada and Blahna [20], in their "Linkages to Public Lands" (LPL) framework, identified five basic categories of rights held by citizens that govern access and use of public resources (Table 1). Whereas most community assessments used in resource planning describe characteristics of nearby communities and then assume some generalized resource-use linkages, LPL differs in that it first lists actual resource-use linkages, and then identifies the communities where the people in those linkages reside [20]. 
Table 1: $\quad$ Types of community-resource linkages [20].

\begin{tabular}{|l|l|}
\hline Linkage & Description \\
\hline $\begin{array}{l}\text { Tribal } \\
\text { linkages }\end{array}$ & $\begin{array}{l}\text { Based on treaty rights, these are unique and special } \\
\text { relationships that have existed over generations between } \\
\text { indigenous peoples and the lands and resources they use. }\end{array}$ \\
\hline $\begin{array}{l}\text { Interest } \\
\text { linkages }\end{array}$ & $\begin{array}{l}\text { Generalized linkages among groups of people that share a } \\
\text { common interest in how public lands are managed. These } \\
\text { linkages give people a say in how resources are managed, even } \\
\text { if they do not actually use the resources. }\end{array}$ \\
\hline $\begin{array}{l}\text { Neighboring } \\
\text { land } \\
\text { linkages }\end{array}$ & $\begin{array}{l}\text { Public and private interests that are linked to public lands } \\
\text { through the ownership or management of lands either within or } \\
\text { adjacent to public land boundaries. }\end{array}$ \\
\hline $\begin{array}{l}\text { Decision- } \\
\text { making } \\
\text { linkages }\end{array}$ & $\begin{array}{l}\text { Institutional and jurisdictional linkages over land and/or } \\
\text { resources that are important because they imply shared } \\
\text { management authority. Examples include cooperation with } \\
\text { local counties or boroughs over emergency services and fire } \\
\text { control. }\end{array}$ \\
\hline $\begin{array}{l}\text { Use } \\
\text { linkages }\end{array}$ & $\begin{array}{l}\text { Established uses that imply a direct physical use of public } \\
\text { lands that are often based upon legal agreements, regulations, } \\
\text { or commonly accepted norms. Examples include timber } \\
\text { harvests, gathering wild fruits, camping, hiking and fishing. }\end{array}$ \\
\hline
\end{tabular}

While each of the community-resource linkages described in Table 1 is important in the Alaskan context, two are prominent. For instance, "tribal linkages" to public lands are central to the existence and identity of many Native communities, and are recognized by the Alaska Native Claims Settlement Act (ANCSA) of 1971 and the Alaskan National Interest Lands Conservation Act (ANILCA) of 1980. Under these laws, Alaskan tribes enjoy access rights to National Forest System (NFS) lands and resources, as well as a "government-togovernment" relationship with state and federal entities. Land management agencies such as the USFS and others are charged with protecting these rights, as well as consulting with tribes over land management activities. Some of these activities include the right to hunt, fish, trap, and gather various materials on NFS lands.

"Use linkages" are also important in the Alaskan context. Here, three subcategories were identified by Endter-Wada and Blahna [20]:

- Open access describes a condition of free access to resources that is available to all. In the U.S. and Alaska, open access is typically allowed, and is best portrayed by recreational and aesthetic enjoyment of forests and access to many ecosystem services.

- Permitted uses require a permit allowing specified users access to resources. These often include fees for the product or service received. In Alaska, this subcategory is unusual in that Alaska Natives can acquire permits without charge to engage in cultural and subsistence 
uses. In such cases, permits are primarily issued for monitoring and planning purposes.

- $\quad$ Illegal uses occur when individuals or groups use resources that are not allowed under open access, or when people engage in permitted uses without a permit.

\section{Community-resource use on the Tongass National Forest}

The Tongass National Forest (TNF) is the largest in the NFS (16.8 million acres). TNF stretches 500 miles along Alaska's coast, and includes over 1,000 islands and a narrow strip of mainland comprised of mountains, ice fields and glaciers. TNF is the world's largest intact temperate rainforest - an ecosystem considered more rare and threatened than tropical rainforest. More than six million acres are protected from logging - an area that includes nearly half TNF's 5.7 million acres of commercial forestland. Southeast Alaska's 74,000 inhabitants reside in 33 mostly rural communities. Many rely on the TNF for employment in the forest products, mining, and recreation sectors, as well as indirectly through activities associated with commercial fishing and processing. The Forest's role in local economic development is particularly important given few opportunities for wage employment and limited private lands.

Subsistence hunting, fishing and gathering of wild foods is also an important cultural and economic activity for many Alaskans - especially among the region's Tlingit, Haida, and Tsimshian peoples. Indeed, Native cultures often have a special relationship with the land that reflects cultural, spiritual, and religious significance. Sacred sites - including mountains, rivers, forests, and burial grounds - are viewed as places of power and significance.

Because of these community-resource linkages, TNF management directly affects the socioeconomic and cultural well-being of nearby communities. For example, in the early 1990s logging on the TNF declined sharply as management shifted from extractive to non-extractive uses, resulting in mill closures, unemployment, and a declining tax base. In response, some communities sought to capitalize on tourism, wildlife viewing and recreation - activities viewed as more sustainable than logging and more compatible with subsistence lifestyles.

\subsection{USFS permits governing private use of public lands}

Permits are required in order to engage in a variety of activities on NFS lands. Activities range from timber harvesting and hunting, to providing guiding services to visitors. The USFS issues permits to: (1) allocate uses to various users; (2) monitor impacts; and (3) collect fees [20]. The Agency maintains two primary public-use permit databases - the Timber Information Manager (TIM) database and the Special Use Database System. TIM, used here, includes:

- $\quad$ Free Use Permits are no-fee permits issued to monitor household use of firewood, sawlogs, and special forest products (SFP) such as burls, bark, berries, ferns, and mushrooms. Alaska law allows residents to harvest 10 MBF of sawlogs and 25 cords of firewood per person/year. 
- $\quad$ Personal Use Permits are fee-based permits that control the above-listed resources that are harvested and sold by households.

- Commercial Use Permits are fee-based permits controlling commercial access to sawlogs, firewood, pulpwood and SFPs.

\subsection{TIM permits issued to residents in TNF communities}

The USFS' TIM permit database represents a ready-source of data that provides insight into how local communities use TNF resources. Here, we develop a simple methodology to map 2007 TIM data in relation to local communities in order to explicitly show the spatial distribution of resource use.

During 2007, 11 communities located within the TNF region received TIM permits (Table 2). These communities varied greatly in terms of population, Native composition, and income. Figure 1 displays the total number of TIM permits issued to residents within each community. Households in Petersburg, Juneau and Ketchikan received the most permits - a finding that in-part reflects the larger population of these communities compared to others in the region (Table 2). In contrast, Figure 2 presents an alternative view of resource use by standardizing permits by the number of households in each community. Here, Meyers Chuck, Tenakee Springs and Point Baker have the highest level of TNF resource dependence when permit use is expressed on a per-1,000 household basis (Figure 2). And as indicated in Table 2, these small communities especially Point Baker and Tenakee Springs which have very low levels of income - are likely to be especially vulnerable to changes in USFS or TNF permitting policies that might restrict local access.

Table 2: $\quad$ Socioeconomic data for communities issued TIM permits in 2007.

\begin{tabular}{|l|l|l|l|l|}
\hline Community & $\begin{array}{c}\text { 2000 } \\
\text { population }\end{array}$ & $\begin{array}{c}\text { Population } \\
\text { change } \\
\mathbf{( 1 9 9 0 - 2 0 0 0 )}\end{array}$ & $\begin{array}{c}\text { Native } \\
\text { Alaskan } \\
\mathbf{( \% )}\end{array}$ & $\begin{array}{c}\text { Median } \\
\text { household } \\
\text { income 2000 }\end{array}$ \\
\hline Craig & 1,397 & $1 \%$ & 30.9 & $\$ 45,298$ \\
\hline Juneau & 36,011 & $1 \%$ & 16.7 & $\$ 62,034$ \\
\hline Kake & 710 & $1 \%$ & 74.6 & $\$ 39,643$ \\
\hline Ketchikan & 7,922 & $2 \%$ & 22.7 & $\$ 45,802$ \\
\hline Meyers Chuck & 21 & $-43 \%$ & 9.5 & $\$ 64,375$ \\
\hline Petersburg & 3,224 & $5 \%$ & 12 & $\$ 49,028$ \\
\hline Point Baker & 35 & $-11 \%$ & 8.6 & $\$ 28,000$ \\
\hline Sitka & 8,835 & $2 \%$ & 24.7 & $\$ 51,901$ \\
\hline Tenakee Springs & 104 & $2 \%$ & 4.8 & $\$ 33,125$ \\
\hline Thorn Bay & 557 & $19 \%$ & 4.8 & $\$ 45,625$ \\
\hline Wrangell & 2,308 & $12 \%$ & 23.8 & $\$ 43,250$ \\
\hline
\end{tabular}




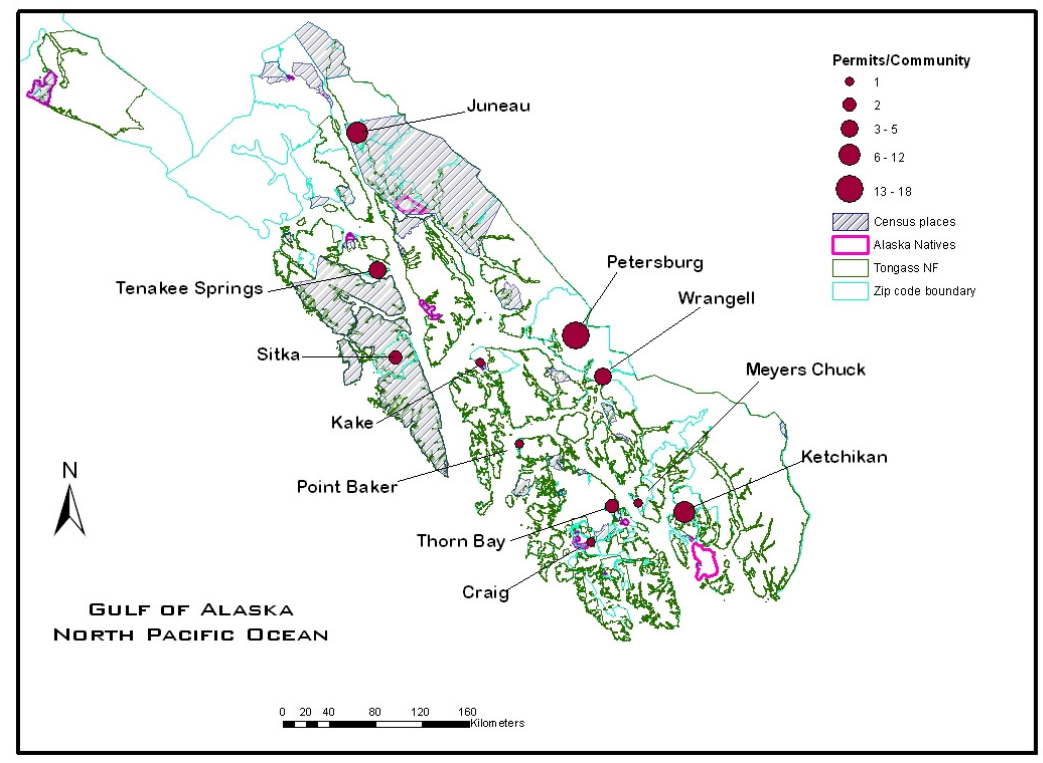

Figure 1: Number of 2007 TIM permits issued to residents in TNF communities.

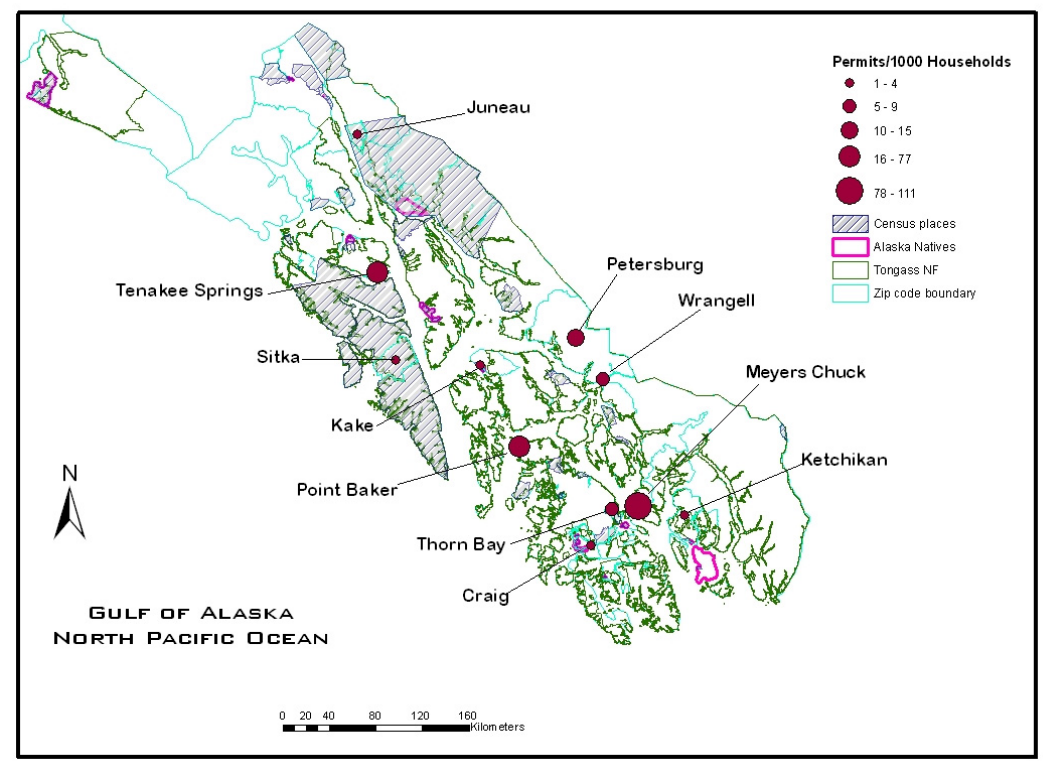

Figure 2: 2007 TIM permits issued per 1,000 households. 


\section{Conclusions}

Sustaining human and natural systems requires information about use, dependence, and vulnerability. Oftentimes such information is depicted at the county or state level using indices derived from employment and income in extractive sectors of the economy. While such measures are important, they tend to mask community-level linkages, and ignore non-extractive uses. In Alaska, understanding local use of public resources at the community level is critical.

In this paper, we presented a simple method that uses existing USFS permit data to depict how local communities use and interact with forests. The method, while restricted to a single permit type and year (i.e., 2007 TIM data), presents a low-cost approach to understanding community-resource linkages that could be easily expanded. Indeed, there are many other types of permits that could form the basis of future work. Most of these data are used to monitor in-forest use. Their expanded use to identify community-resource linkages could prove an important step in improving community assessments of dependency and vulnerability $[20,21]$.

\section{References}

[1] Kruger, L. \& Mazza, R., Alaska Communities and Forest Environments: A Problem Analysis \& Research Agenda. USFS Report PNW-GTR-665, 2006.

[2] Kennedy, J. \& Koch, N., Viewing and managing natural resources as human-ecosystem relationships. For. Pol. \& Econ., 6, pp. 497-504, 2004.

[3] Wilkinson, K.P., The Community in Rural America. Yale Univ., Dissertation Services, Ann Arbor, 1991.

[4] Force, J.E., Machlis, G.E. \& Zhang, L., The engine of change in resourcedependent communities. For. Sci., 46(3), pp. 410-422, 2000.

[5] Flora, C.B., Flora, J.L. \& Fey, S., Rural Communities: Legacy and Change $2^{\text {nd }}$ ed. Westview Press: Boulder, CO, 2004.

[6] Allen, S.D., Robertson, G. \& Schaefers, J., Economies in transition: An assessment of trends relevant to management of the Tongass National Forest. USFS Report PNW-GTR-417, 101 pp., 1998.

[7] Berck, P., Costello, C., Fortmann, L. \& Hoffman, S., Poverty and employment in forest-dependent counties. For. Sci., 9(5), pp. 763-776, 2003.

[8] Kaufman, H.F. \& Kaufman, L.C., Toward the Stabilization and Enrichment of a Forest Community. USFS Report, 1946.

[9] Overdevest, C. \& Green, G., Forest dependence and community well-being: A segmented market approach. Soc. \& Nat. Res., 8, pp. 111-131, 1995.

[10] Freudenburg, W.R. \& Gramling, R., Natural resources and rural poverty: A closer look. Soc. \& Nat. Res., 7, pp. 5-22, 1994.

[11] Tsournos, P. \& Haynes, R.W., An Assessment of Growth and Development Paths for Southeast Alaska. USFS Report PNW-GTR-620, 2004. 
[12] Haynes, R.W., Assessing the Viability and Adaptability of ForestDependent Communities in the United States. USFS Report PNW-GTR$567,2003$.

[13] Kusel, J., Assessing Well-Being in Forest-Dependent Communities. USFS Report PNW-GTR-566, 2003.

[14] Harris, C., McLaughlin, W.J. \& Brown G., Rural communities in the interior Columbia Basin: How resilient are they? J. For., 96(3), pp. 11-15, 1998.

[15] Beckley, T., Parkins, J. \& Stedman, R., Indicators of forest-community sustainability: The evolution of research. For. Chron., 78(5), pp. 626-636, 2002.

[16] Krannich, R.S. \& Lulof, A.E., Problems of resource dependency in U.S. rural communities. Rural Policy and Planning, ed. A. Gilg, Belhaven Press: London, pp. 5-18, 1991.

[17] Blaikie, P., Cannon, T., Davis, I. \& Wisner, B., At Risk: Natural Hazards, People's Vulnerability and Disasters, Routledge: London, 1994.

[18] Cash, D., Adger, W., Berkes, W.N., Garden, F., Lebel, P., Olsson, L., Pritchard, P.L. \& Young, L.O., Scale and cross-scale dynamics: Governance and information in a multi-level world. Ecol. \& Soc., 11(2), pp. 8-17, 2006.

[19] Berkes, F., Commons in a multi-level world. Int'l J. of the Commons, 2(1), pp. 1-6, 2008.

[20] Endter-Wada, J. \& Blahna, D.J., Linkages to the public lands: A framework for social assessment and impact analysis on public lands. In Proc. Int'1 Symp. Soc. \& Res. Mgt., Keystone, CO, 2004.

[21] Charnley, S., Donoghue, E.M. \& Moseley, C., Forest management policy and community well-being in the Pacific Northwest. J. For. 106(8), pp. 440-447, 2008. 